\title{
Emerging from the Shadows: Substantive Equality and Article 14 of the European Convention on Human Rights
}

\section{Introduction}

At first sight, the equality guarantee in Article 14 of the European Convention on Human Rights (ECHR) appears relatively insipid. Labelled as a 'parasitic' right, it only prohibits discrimination in the enjoyment of other Convention rights and is regarded by the European Court of Human Rights as having no independent existence. Indeed, it was this feature that led the Council of Europe to adopt a self-standing equality guarantee in the form of Protocol 12 in 2000. A look at the jurisprudence of the Court in the last few years yields a very different picture. The Court has held that refusal to afford equal parental rights to fathers is a breach of Article 14; that violence against women is a form of gender discrimination; that segregation in education can constitute race discrimination; that unequal treatment on grounds of sexual orientation is unjustifiable in a growing number of contexts; and that social benefits, even if they do not constitute rights in themselves, should not be granted on a discriminatory basis. This raises the question of whether we can now discern a coherent conception of the right to equality, which incorporates the insights of substantive equality being developed in other courts and in the scholarship. This paper aims to address this question by assessing recent developments in Article 14 jurisprudence.

I begin by considering the structure of Article 14 and the ways in which the Court has interpreted its component parts to allow the evolution of a broader and more searching conception of equality than in its early jurisprudence. Particularly important have been the elasticity of the grounds of discrimination; the fluidity of the concept of 'ambit'; and the preparedness to develop the concept of 'discrimination' to include more substantive conceptions such as indirect discrimination. Also significant has been the Court's openness to absorbing conceptions of discrimination and equality that have developed in other arenas, particularly the European Union (EU). In Part II, I evaluate these developments against a framework of substantive equality, based on four dimensions, namely: redressing disadvantage (the redistributive dimension); addressing stigma, stereotyping, prejudice and violence (the recognition dimension); facilitating voice and participation (the participative 
dimension); and accommodating difference, including through structural change (the transformative dimension). I conclude that although not explicitly articulated, the recent ECHR jurisprudence on Article 14 contains many glimmers of substantive equality, particularly in relation to the first three dimensions. The fourth, or transformative dimension, remains the most challenging, perhaps not unexpectedly, given the Court's positioning as a supra-national tribunal.

Article 14 ECHR should not, of course, be seen in isolation. It operates in a relatively crowded European space so far as equality is concerned. The right to equal pay for equal work for men and women was the only equality provision in the original Treaty of Rome outside of the freedom of movement provisions. ${ }^{1}$ However, from the mid 1970s, there have been numerous developments in relation to gender equality in the EU, whether through Treaty amendments, directives, or case-law. From 1998, the EU gained competence to legislate in relation to age, disability, sexual orientation, religion or belief, and racial or ethnic origin, leading to two new directives in $2000 .^{2}$ This is complemented by the EU Charter of Fundamental Rights, which has a chapter on equality. ${ }^{3}$ Adopted in 2000, the EU Charter now has binding force in the EU. Because it is directly binding on member states, EU jurisprudence is inevitably more powerful in its effect than that of the ECHR. Nevertheless, Article 14 plays an important role. It covers more European countries than the EU; and its remit is different, referring to Convention rights rather than employment, which is the primary site of EU anti-discrimination law. ${ }^{4}$ Article 14 should also be seen in the context of the European Social Charter. ${ }^{5}$

\section{Emerging from the shadows}

'The enjoyment of the rights and freedoms set forth in this Convention shall be secured without discrimination on any ground such as sex, race, colour, language, religion, political or other opinion, national or social origin, association with a national minority, property, birth or other status.' (Article 14 ECHR).

\footnotetext{
${ }^{1}$ Article 119 Treaty of Rome, 289 UNTS 3

${ }^{2}$ Council Directive 2000/43/EC implementing the principle of equal treatment between persons irrespective of racial or ethnic origin [2000] OJ L 180; Council Directive 2000/78/EC establishing a general framework for equal treatment in employment and occupation [2000] OJ L 303.

${ }^{3}$ Charter of Fundamental Rights of the European Union [2012] OJ C 326/391, Chapter III.

${ }^{4}$ Directive 2000/43 EC, supra note 2 also covers social protection; social advantages; education; and public goods and services; and the various gender directives cover public goods and services.

${ }^{5}$ Council of Europe, European Social Charter (Revised), 3 May 1996, ETS 163, Article E; Article 20.
} 
A glance at Article 14 reveals three key characteristics. Firstly, it is structured as a parasitic or dependent right. It guarantees only that 'the enjoyment of the rights in this Convention shall be secured without discrimination' on the mentioned grounds. This contrasts with Protocol 12, which prohibits discrimination in relation to any 'right set forth by law;' as well as discrimination by a public authority, on the same grounds as are mentioned in Article 14 . Secondly, the list of enumerated grounds is a product of its time. Some seem less pressing now than they did then, whereas current key issues, such as disability, sexual orientation and age, are missing. On the other hand, the list is non-exhaustive. It is prefaced by 'such as', suggesting that they are only illustrative, and ends with 'other status.' The third characteristic relates to the concept of discrimination, which is mentioned but not defined. This part considers the expansive interpretation that the Court has given to each of these characteristics.

\section{A. Widening the threshold: from breach to ambit}

The early case law of the court assumed that, before Article 14 could come into play, a breach of one of the substantive rights had to be proved. It was not surprising therefore, that Article 14 often appeared redundant: if the right had been breached, no further energy needed to be expended on considering Article 14; but if the right had not been breached, Article 14 was not applicable in any event. ${ }^{6}$ However, as a closer look at the wording of Article 14 reveals, the Convention requires that the 'enjoyment' of Convention rights 'shall be secured without discrimination,' rather than that there should be a breach as a precondition to the operation of Article 14. It was thus of critical importance for the development of Article 14 that the Court began to move from 'breach' to 'ambit'.

This development started as early as Belgian Linguistics in 1968. The Belgian Government submitted before the Commission that a violation of Article 14 without simultaneous violation of another Article of the Convention was 'legally impossible'. ${ }^{7}$ The Commission, however, suggested that a breach of the substantive right was not necessary: it was enough for the discrimination at issue to 'touch the enjoyment' of a specific right or

\footnotetext{
${ }^{6}$ For a recent example, see Mileusnic and Mileusnic-Espenheim v Croatia, Application No 66953/09, Merits, 19 February 2015 at para 74; Oliari v Italy, Applications No. 18766/11 and 36030/11,Merits, 21 July 2015.

${ }^{7}$ Belgian Linguistics (No 2), Application no 1474/62; 1677/62; 1691/62; 1769/63; 1994/63; 2126/64, Merits, 23 July 1968
} 
freedom. ${ }^{8}$ This approach, which was accepted by the Court, ${ }^{9}$ has now become settled law. According to the formula regularly used by the Court, 'For Article 14 to become applicable it suffices that the facts of a case fall within the ambit of another substantive provision of the Convention or its Protocols.' 10

One of the most important implications of the 'ambit' principle is that Article 14 can extend 'beyond the enjoyment of the rights which the Convention requires each State to guarantee. It applies also to those additional rights, falling within the general scope of any Convention Article, for which the State has voluntarily decided to provide.' 11 This is epitomised in EB $v$ France, which concerned discrimination against a gay woman who wished to adopt a child. ${ }^{12}$ The Court made it clear that Article 8 did not expressly give a right to a single person to adopt a child. Nevertheless, adoption clearly fell within the ambit of Article 8. The result was that 'the State, which has gone beyond its obligations under Article 8 in creating such a right cannot in the application of that right, take discriminatory measures within the meaning of Article 14. ${ }^{\text {13 }}$

The result has been far reaching. While not establishing socio-economic rights as such, it has had the effect of extending existing social provisions in social democratic European States to excluded groups. Thus in Belgian Linguistics itself, the Court held that the education provision in Article 2 of Protocol 1 does not give individuals the right to a particular kind of educational establishment. However, a State that does set up such an establishment cannot do so in a discriminatory manner. ${ }^{14} \mathrm{~A}$ similar result for the right to housing can be seen in Baroness Hale's statement in the UK case of Ghaidan: 'Everyone has the right to respect for their home. This does not mean that the state-or anyone else- - has to supply everyone with a home. ... But if it does grant that right to some, it must not withhold it from others in the same or an analogous situation. ${ }^{15}$ This has extended too to welfare benefits. In Stec, ${ }^{16}$ the Court reiterated that the right to peaceful enjoyment of property in Article 1 Protocol 1 'does not create a right to acquire property. It places no restriction on the Contracting State's freedom to decide whether or not to have in place any form of social

\footnotetext{
8 Ibid. at para 7.

${ }^{9}$ Ibid. at para 8.

10 Thlimmenos v Greece, Application No. 34369/97, Merits, 6 April 2000; most recently see Hämäläinen v Finland, Application No. 37359/09, Merits, 16 July 2014.

${ }^{11}$ EB v France, Application No. 43546/02, Merits, 22 Janury 2008 at para $47-48$.

12 Ibid.

${ }^{13}$ Ibid. at para 49.

${ }^{14}$ Belgian Linguistics (No 2) supra $n 7$ at para 9.

15 Ghaidan v. Godin-Mendoza [2004] UKHL 30, [2004] 2 A.C. 557 (HL).

${ }^{16}$ Stec $v$ United Kingdom, Applications Nos. 65731/01 and 65900/01, Merits, 12 April 2006.
} 
security scheme, or to choose the type or amount of benefits to provide...' Nevertheless, it held: 'If, however, a Contracting State has in force legislation providing for the payment as of right of a welfare benefit contributions...that legislation must be regarded as generating a proprietary interest falling within the ambit of [Article 1] for persons satisfying its requirements ${ }^{17}$ This means that benefits which it does provide must comply with Article 14 . This expansive view of the scope of Article 14 has meant that in practice Protocol 12 has proved less relevant than first imagined. ${ }^{18}$

\section{B. Elasticity of Grounds}

The list of grounds in Article 14 differs from its parallel in EU law in including language, political or other opinion, national or social origin, association with a national minority, property, and birth. Conspicuous by their absence, however, are disability, sexual orientation and age. Here too the ECtHR has adopted an expansive approach. Thus the Court has frequently reiterated that the list in Article 14 is 'illustrative and not exhaustive, as is shown by the words "any grounds such as.", 19 In addition, the words “ "other status” have generally been given a wide meaning, not limited to characteristics which are innate or inherent. ${ }^{20}$ Instead, the Court regards the Convention as a living instrument, to be interpreted in light of present day conditions. ${ }^{21}$

This has made it relatively easy to extend the scope of Article 14 to include some of the major missing grounds. Thus in Salgueiro da Silva Mouta, the Court was able to conclude that sexual orientation was 'undoubtedly covered by Article 14.' 22 The inclusion of disability has been accepted with equally little fuss; ${ }^{23}$ and in Kiyutin $v$ Russia, the Court held that a distinction on account of an individual's health status should be covered, either as a disability

\footnotetext{
17 Ibid.

18 There are 18 ratifications of Protocol 12 as of 30 May 2015, available at: http://conventions.coe.int/Treaty/Commun/ChercheSig.asp?NT=177\&CM=\&DF=\&CL=ENG [last accessed 12 June 2015]; compared to 47 ratifications of the ECHR, available at: http://conventions.coe.int/Treaty/Commun/print/ChercheSig.asp?NT=005\&CM=\&DF=\&CL=ENG [last accessed 12 June 2015]. But see partly dissenting opinion of Judge Spano in Boyraz v Turkey, Application No. 61960/08, Merits, 2 December 2014 objecting that the wide ambit of Article 14 made Protocol 12 redundant.

19 Salgueiro da Silva Mouta v Portugal, Application No. 33290/96, Merits, 21 December 1999.

${ }^{20}$ Kiyutin v Russia, Application No. 2700/10, Merits, 10 March 2011 at para 56; Gerards, 'The Discrimination Grounds of Article 14 of the European Convention on Human Rights' (2013) 13 Human Rights Law Review 99.

${ }^{21}$ Inze v Austria, Application No. 8695/79, Merits, 28 October 1987.

22 Salgueiro da Silva Mouta, supra n 19 See also SL v Austria, Application No. 45330/99, Merits, 9 January 2003 and many other cases.

${ }^{23}$ Glor v Switzerland, Application No. 13444/04, Merits, 30 April 2009 at para 80.
} 
or as a form thereof. This meant that discrimination on grounds of HIV status could fall within the Article. ${ }^{24}$ Article 14 has also been held to cover distinctions between children born in and out of wedlock; ${ }^{25}$ and in Schwizgebel, the Court was prepared to consider a distinction on grounds of age as potentially within Article $14 .{ }^{26}$ This expansive approach has become so well accepted in the jurisprudence of the Court that when Protocol 12 was drafted, it was decided against expressly including the additional grounds that were so blatantly missing from Article 14. As the explanatory notes state, this was not because of a lack of awareness that such grounds have become particularly important in today's societies. Instead, it was considered unnecessary since the list of grounds is not exhaustive, and inclusion of any particular additional ground might give rise to unwarranted a contrario interpretations in relation to grounds not so included. ${ }^{27}$

The Court's openness to regarding most classifications as falling within the rubric of 'other status' has, however, led it to filter claims through a varying standard of scrutiny. Contracting States enjoy a margin of appreciation in assessing to what extent differences in otherwise similar situations justify different treatment. However, for particular grounds, the margin of appreciation is narrow. The Court requires 'particularly convincing and weighty reasons' before it regards a difference of treatment based exclusively on ethnic origin; ${ }^{28}$ gender; ${ }^{29}$ sexual orientation; ${ }^{30}$ and disability ${ }^{31}$ as compatible with the Convention. On the other hand, the margin of appreciation is wide in relation to social or economic policies; with the Court deferring to the legislature's judgement unless it is 'manifestly without reasonable foundation.' ${ }^{32}$ It also looks closely at whether there is common ground between Contracting States on the issue. ${ }^{33}$ For other grounds, such as religion, the margin of appreciation is still in flux. In SAS v France, the Court gave the State wide margin of appreciation in justifying the

\footnotetext{
${ }^{24}$ Kiyutin, supra n 20 at para 58.

${ }^{25}$ Inze, supra n 21.

26 Schwizgbel v Switzerland, Application No. 25762/07, Merits, 10 June 2010.

${ }^{27}$ Protocol No. 12 to the European Convention on Human Rights: Explanatory Report, available at: http://conventions.coe.int/Treaty/EN/Reports/Html/177.htm [last accessed 12 June 2015].

${ }^{28}$ DH v Czech Republic Application No.57325/00, Merits, 13 November 2007.

${ }^{29}$ Abdulaziz, Cabales and Balkandali v UK, Application no. 9214/80; 9473/81; 9474/81, Merits, 28 May 1985.

${ }^{30}$ EB, supra note 11; X v Austria, Application No. 19010/07, Merits, 19 February 2013. .

31 Kiss v Hungary, Application no. 11146/11, Merits, 29 January, 2013.

32 Stec v United Kingdom supra n 17; Connors v United Kingdom, Application no. 66746/01, Merits, 27 May 2004.

${ }^{33}$ Petrovic v Austria, Application No. 20458/92, Merits, 27 March 1998; Hämäläinen supra n 11.
} 
discriminatory effect on Muslim women of the French ban on wearing a full-face veil in public. ${ }^{34}$

\section{Defining Discrimination}

The Convention simply states that the enjoyment of the rights should be secured 'without discrimination' on the grounds mentioned. Discrimination is not further defined. From its earliest case-law, the Court began to develop an understanding which regarded discrimination in terms of distinctions which were not justifiable. As the Court put it in Belgian Linguistics, ${ }^{35}$ it would be absurd to regard Article 14 as prohibiting every difference in treatment. Instead, Article 14 is only violated if the impugned distinction has no objective and reasonable justification. ${ }^{36}$ This puts the main weight of decision on the definition of justification. For this the Court has always used a classic proportionality doctrine. In a formula that is now standard in Article 14 cases, the Court stated: 'A difference in treatment in the exercise of a Convention right must not only pursue a legitimate aim. Art 14 is also violated when there is no reasonable relationship of proportionality between the means employed and the aim sought to be realised. ${ }^{37}$ This formulation was restated in almost identical terms by the Grand Chamber in 2015 in Hämäläinen v. Finland. ${ }^{38}$

For many years, the Court based its decisions on a formal view of equality, namely that likes should be treated alike. This was despite the development of a doctrine of disparate impact or indirect discrimination, which had been pioneered by the US Supreme Court ${ }^{39}$ and subsequently incorporated into UK and EU anti-discrimination law. Recognising that equal treatment can entrench disadvantage in situations of antecedent inequality, indirect discrimination or disparate impact focuses on inequality of results rather than inequality of treatment, unless it can be justified. The ECtHR's refusal to investigate the disparate results of equal treatment is most clearly evidenced in Abdulaziz in $1985 .{ }^{40}$ The applicants argued

\footnotetext{
${ }^{34}$ SAS v France, Application No. 43835/11, Merits, 1 July 2014; see generally O Arnardo'ttir, 'The Differences that Make a Difference: Recent Developments on the Discrimination Grounds and the Margin of Appreciation under Article 14 of the European Convention on Human Rights' €(2014) 14 Human Rights Law Review 647 ${ }^{35}$ Belgian Linguistic Case (No 2) supra n 14.

${ }^{36}$ Ibid. at para 10.

${ }^{37}$ Ibid. at para 10.

${ }^{38}$ Hamalainen, supra n 11 at para 108.

${ }^{39}$ Griggs v. Duke Power Co. 401 U.S. 424 (1971) (US Supreme Court)

40 Abdulaziz, Cabales and Balkandali, supra n 20.
} 
that newly adopted immigration rules in the UK, while treating everyone equally, disproportionately excluded applicants from the New Commonwealth and Pakistan. The Court roundly rejected this approach. 'That the mass immigration against which the rules were directed consisted mainly of would-be immigrants from the New Commonwealth and Pakistan, and that as a result they affected at the material time fewer white people than others, is not a sufficient reason to consider them as racist in character: it is an effect which derives not from the content of the 1980 Rules but from the fact that, among those wishing to immigrate, some ethnic groups outnumbered others. ${ }^{41}$

More recently, however, the Court's jurisprudence has developed well beyond the equal treatment doctrine. There are some hints as far back as Belgian Linguistics, where the Court recognised that in some contexts, legal inequalities might be necessary to correct factual inequalities. ${ }^{42}$ But the first real breakthrough beyond the equal treatment model came in Thlimmenos. ${ }^{43}$ In this case, the applicant had been refused entry into the accountancy profession because he had a criminal conviction. This rule was applied uniformly to all candidates for accountancy. However, for Thlimmenos, the criminal conviction arose from his conscientious objection on religious grounds to compulsory military service. Here the Court recognised that equal treatment could be discriminatory. This important step beyond an equal treatment model was summed up in this way: 'The Court has so far considered that Article 14 is violated when States treat differently persons in analogous situations without providing an objective and reasonable justification. [Article 14] is also violated when States without an objective and reasonable justification fail to treat differently persons whose situations are significantly different. ${ }^{44}$

The Thlimmenos doctrine did not, however, amount to a fully fledged principle of indirect discrimination. For this, we had to wait for $\mathrm{DH} v$ Czech Republic. ${ }^{45}$ In this case, Roma children were disproportionately allocated to ‘special' schools, delivering inferior education, due to the way in which educational tests were framed and administered. The Chamber held that the same educational tests were applied to all Czech pupils and therefore could not be discriminatory. ${ }^{46}$ The Grand Chamber reversed this decision. ${ }^{47}$ Picking up on the

\footnotetext{
41 Ibid.

42 Belgian Linguistic Case (No 2), supra n 14 at para 10.

43 Thlimmenos, supra $\mathrm{n} 10$.

${ }^{44}$ Ibid. at para 44.

${ }^{45} \mathrm{DH}$, supra n 29.

${ }^{46}$ D.H. v Czech Republic , Application No. 57325/00, Merits, 7 February 2006.

${ }^{47} \mathrm{DH} v$ Czech Republic supra n 29.
} 
concept of indirect discrimination in EU law, the Court held that 'a difference in treatment may take the form of disproportionately prejudicial effects of a general policy or measure which, though couched in neutral terms, discriminates against a group. ${ }^{48}$ Particularly important was its emphasis on the fact that indirect discrimination does not necessarily require discriminatory intent. This was reinforced in the similar case of Oršuš. ${ }^{49}$

The Court's jurisprudence nevertheless continues to differ from parallel jurisdictions such as that of the EU and the UK in leaving open the possibility of a justification defence in both equal treatment (or direct discrimination) and indirect discrimination claims. Both the CJEU and the UK have resolutely opposed allowing a general justification defence for direct discrimination. ${ }^{50}$ By contrast, the ECtHR has preferred to calibrate the strictness of the standard of justification depending on the ground and context. In Sejdic, the applicants invited the Court to follow EU jurisprudence and hold that difference in treatment based expressly on race or ethnicity was not capable of justification and amounted to direct discrimination. ${ }^{51}$ The Court rejected this approach, largely because of the danger that a blanket refusal to allow justification would also outlaw affirmative action. ${ }^{52}$ Thus it held that, 'where a difference in treatment is based on race or ethnicity, the notion of objective and reasonable justification must be interpreted as strictly as possible.' Nevertheless, 'Article 14 does not prohibit Contracting Parties from treating groups differently in order to correct "factual inequalities" between them. Indeed, in certain circumstances a failure to attempt to correct inequality through different treatment may, without an objective and reasonable justification, give rise to a breach of that Article. ${ }^{53}$

What risks then are associated with permitting justification for direct discrimination, and have these materialised in ECHR jurisprudence? One argument has been that permitting direct discrimination to be excused is a central affront to individual dignity. A different concern is those employers' business costs or customer prejudice might be seen as a good

\footnotetext{
48 Ibid. at para 184.

49 Oršuš v Croatia, Application No. 15766/03, Merits, 16 March 2010 at para 150.

50 See $R$ (on the application of E) v Governing Body of JFS and the Admissions Appeal Panel of JFS [2009] UKSC 15.

51 Sejdić and Finci v. Bosnia and Herzegovina, Applications nos. 27996/06 and 34836/06, Merits, 22 December 2009.

52 US jurisprudence has oscillated widely between accepting affirmative action as a means to achieve (substantive) equality and rejecting it as a breach of (formal) equality: Ricci v. DeStefano 129 S. Ct. 2658 (2009) (US Supreme Court) The EU permits affirmative action as an exception to the equal treatment principle only when it does not disrupt the merit principle, that is in 'tie-break' situations:C-450/93 Kalanke v Freie Hansestadt Bremen, [1996] ECR I-0305.

53 Sejdić and Finci, supra n 51 at para 44.
} 
reason to permit discrimination. ${ }^{54}$ There is also a danger that stereotypes might be reinforced if less favourable treatment on a protected ground can be justified. ${ }^{55}$ On the other hand, a rigid refusal to allow justification makes it difficult to correct factual inequalities by treating different groups differently. The lack of acceptable justification is also problematic when two types of discrimination conflict, such as religion and race, gender or sexual orientation. The knowledge that a finding of discrimination is determinative of the matter might lead courts to avoid this outcome by taking a restrictive view of earlier threshold requirements, such as whether the applicant is a 'worker. ${ }^{56}$ It is arguable, therefore, that instead of a rigid refusal to permit justification, it would be preferable to apply justification strictly to prevent stereotyping and other invidious discrimination, but to permit appropriate differentiation where necessary to advance the background goal of equality.

In fact, the Strasbourg court has shown itself to be capable of resisting attempts to use justification to permit invidious direct discrimination, as demonstrated by the very recent case of Emel Boyraz v Turkey. ${ }^{57}$ In this case, the applicant had been denied a position as a security officer in the State-run electricity company because she was a woman. Although she had successfully written the public service examination, she was informed that she could not be appointed as she did not fulfil the criterion of being a man. The State justified this exclusion on the grounds that the job required the incumbent to handle weapons, work day and night and use physical force in case of an attack, for which women were not suitable. The Court took the high standard of justification for sex discrimination seriously, reiterating that, since 'the advancement of gender equality is today a major goal in the member States of the Council of Europe ... very weighty reasons would have to be put forward before such a difference of treatment could be regarded as compatible with the Convention. ${ }^{58}$ No explanation had been given as to why women were incapable of fulfilling the requirements of the job. The Court concluded that 'the mere fact that security officers had to work night shifts and in rural areas and might be required to use physical force and firearms under certain conditions could not in itself justify the difference in treatment between men and women.'59

\footnotetext{
${ }^{54}$ Gill and Monaghan, 'Justification in Direct Sex Discrimination Law: Taboo Upheld' (2003) 32 Industrial Law Journal 115

${ }^{55} R$ (European Roma Rights Centre and Others) v Immigration Officer at Prague Airport [2004] UKHL 55.

${ }^{56}$ Hashwani $v$ Jivraj [2011] UCKSC 40; see McCrudden, 'Two Views of Subordination: The Personal Scope of Employment Discrimination Law in Jivraj v Hashwani ' (2012) 41 Industrial Law Journal 30 ; Freedland and Kountouris, ' Employment Equality and Personal Work Relations-A Critique of Jivraj v Hashwani' (2012) 41 Industrial Law Journal 56

${ }^{57}$ Boyraz, supra n 18.

${ }^{58}$ Ibid. at para 51.

${ }^{59}$ Ibid. at para 54.
} 
The existence of a possible justification defence is not, therefore, problematic. The real challenge is for it to be calibrated in a manner which can discern invidious discrimination and distinguish it from appropriate differentiation.

\section{Article 14 and Substantive Equality}

\section{A. Substantive Equality: A Four-Dimensional Approach}

To what extent, then, can the Court be regarded as developing a conception of substantive equality? Substantive equality is itself a contested concept, to which a range of meanings has been attributed. Rather than attempting to pin substantive equality to a single meaning, such as equality of opportunity, equality of results, or dignity, it is submitted that it should be understood as a multi-dimensional concept, pursuing four complementary and inter-related objectives. ${ }^{60}$ These are: redressing disadvantage (the redistributive dimension); addressing stigma, stereotyping, prejudice and violence (the recognition dimension); facilitating participation (the participatory dimension); and accommodating difference, including through structural change (the transformative dimensions). These are elaborated briefly below.

The redistributive dimension aims to redress disadvantage. The formal equality or 'anti-classification' approach requires the removal of 'irrelevant' classifications such as race and sex, the aim being that each individual should be treated on merit. Substantive equality, by contrast, recognises that there is no abstract individual and merit itself might be a function of previous discrimination. Classifications are invidious when they lead to detriment or disadvantage, but they may be necessary to compensate for previous disadvantage. Substantive equality therefore aims to redress disadvantage, rather than prohibiting classification. This has several advantages. It incorporates the insights of indirect discrimination, recognising that equal treatment can constitute a breach of substantive equality if there is disparate impact. It goes further, and permits affirmative action or expressly differential treatment to redress previous disadvantage. Nor can it be argued that equality can be achieved by levelling down, or removing a benefit from the better off. This would not be redressing disadvantage. Disadvantage in this context is primarily concerned

\footnotetext{
${ }^{60}$ Fredman, Discrimination Law, 2nd ed (2011) 25 - 33.
} 
with socio-economic disadvantage; but it also extends to non-material disadvantages, such as subordination and imbalances in power, whether within the family or outside of it.

The recognition dimension of substantive equality aims to capture the familiar association of the right to equality with dignity, while avoiding its pitfalls, namely that it is vague $^{61}$ and oblivious of social relations. Instead of an open-ended conception of dignity, this dimension of substantive equality specifies the wrong to be addressed as stigma, stereotyping, prejudice and violence based on a protected characteristic. Similarly, rather than an individualised notion of dignity, this draws on Nancy Fraser's conception of 'recognition wrongs', which consist in 'misrecognition' or inequality in the mutual respect and concern that people feel for one another in society. ${ }^{62}$ Based on the Hegelian notion that our identity is constructed (at least partially) in terms of the ways in which others regard us, recognition wrongs can be experienced regardless of relative socio-economic disadvantage or distributive wrongs.

The participative dimension of substantive equality draws on Ely's insight that the aim of judicial review is to compensate for the absence of political power of groups who are permanently marginalised and therefore 'to whose needs and wishes elected officials have no apparent interest in attending' ${ }^{63}$ Substantive equality requires decision-makers to hear and respond to the voices of groups sharing a protected characteristic rather than imposing topdown decisions. Substantive equality also has the important effect of imposing positive duties on the state to ensure that those affected have the capacity to participate meaningfully. This dimension also refers to social exclusion, whether through age, poverty, disability or confinement in the private sphere of the family.

The transformative dimension of substantive equality arises from the recognition that equality is not necessarily about sameness. Different identities and characteristics should be respected and even celebrated. Difference should not, however, attract detriment, and nor should assimilation be required as a precondition for the right to equality. This in turn might require structures to be modified or transformed to accommodate difference. For example, rather than requiring women to conform to male norms, substantive equality requires transformation of existing male-oriented institutions and social structures. With this comes the imperative to transcend the public-private divide, recognizing the ways in which

\footnotetext{
${ }^{61}$ McCrudden, "Human dignity and judicial interpretation of human rights' (2008) European Journal of International Law 655

${ }^{62}$ Fraser and Honneth, Redistribution or Recognition (2003) at 29.

${ }^{63}$ Ely, Democracy and Distrust: A Theory of Judicial Review (1980) at 46.
} 
imbalances in power in the family can reinforce power imbalances in the public sphere and vice versa. This in turn entails the requirement of positive duties to achieve equality as well as negative duties to prevent discrimination. Substantive equality also requires the accommodation of differences within groups.

One of the key advantages of a multi-dimensional approach is that it provides a framework within which to address the interaction between dimensions. Rather than viewing one as a trump over the others, the dimensions should mediate each other, leading to a synthesis or more nuanced response. For example, welfare benefits might address disadvantage, but be delivered in such a way as to stigmatise the beneficiaries. Affirmative action measures can similarly redress disadvantage while at the same time causing stigma. The four-dimensional approach makes it possible to address these tensions. Given that equality aims to redress disadvantage as well as to address stigma, it is crucial to design both welfare and affirmative action measures in ways that advance dignity as well as redressing disadvantage. Furthermore, measures aimed at redressing disadvantage or reducing stigma may not go far enough towards achieving substantive equality unless accompanied by structural change. For example, since women predominate among part-time workers, equal hourly pay for part-time workers is an important measure to redress the disadvantage of women in labour market. But until the division of labour in the home is addressed, the gender composition of the part-time workforce is unlikely to change. Similarly, the participation dimension might mask a possible disjuncture between those who speak and those who are affected. Combined with the requirement that disadvantage be redressed, however, would result in paying attention to ensuring that the least vocal are heard. The multi-dimensional approach also makes it impossible to argue, as courts in both Canada and the UK have done, that a measure aggravating socio-economic disadvantage is not a breach of the right to equality because it was not meant to stigmatise the victims. ${ }^{64}$

A key question in relation to substantive equality is the role of agency or choice. While enhanced agency and choice might seem to be an aim of substantive equality, liberal theories of choice have periodically been used to defeat equality claims on the grounds that the claimant could have chosen to avoid the consequences of a policy or practice. Adverse consequences are then attributed to the claimant's own choices. ${ }^{65}$ On this view, individuals should only be protected against detrimental treatment on the basis of characteristics that are

\footnotetext{
${ }^{64}$ Gosselin v Quebec 2002 SCC 84; see now $R$ v Kapp 2008 SCC 41.

${ }^{65}$ D.H., supra n 46; see further below.
} 
'immutable' or cannot be changed by the applicants’ own efforts. Substantive equality has brought with it an acknowledgement that that an individual should not be made to pay an unreasonable price for her choices. ${ }^{66}$ More fundamentally, the capabilities theory of Amartya Sen has helpfully illuminated the distinction between abstract choice and feasible options. Because the role of choice in substantive equality needs to be carefully nuanced, it is not regarded as a separate dimension within the four dimensional framework. Instead, the appropriate notion of agency should be constructed within the four dimensions. For example, the need to redress disadvantage can override apparent choice when such choices are limited by that very disadvantage, or choices appear to entrench disadvantage. Similarly, recognition issues are based on the actual consequences flowing from one's identity, regardless of whether and to what extent that identity is chosen. The exercise of choice could be seen to be fulfilling the participative dimension, but this too needs to be carefully balanced against the need to redress disadvantage, including constrained choice. Under the transformative, dimension agency can be enhanced, through changing structures to widen the range of feasible options. However, for many identities choice is not the only value to strive for but should be complemented by the possibility of valuing the situation people find themselves in regardless of choice.

The following sections analyse recent developments through the prism of a multidimensional understanding of substantive equality with the aim of drawing together the fragments into a more coherent whole and highlighting the missing links. For reasons of space, this paper focuses on race, gender, sexual orientation and disability, with the hope that other cases, particularly those relating to religion, can be similarly analysed in a future project.

\section{B. Race and minority status:}

Race discrimination in Europe can be seen to operate along all four of the axes identified above as the basis of substantive equality: first, a cycle of disadvantage; second, stigma, stereotyping, prejudice, and violence; thirdly, lack of voice and exclusion from political and social decision-making; and finally the negation and even obliteration of culture, religion, or language. Ethnic and national minorities frequently face discrimination and exclusion from employment, housing, education and access to health services and justice. Such material

\footnotetext{
${ }^{66}$ See for example Mandla v Lee, [1983] 2 AC 548 (HL).
} 
disadvantage is intricately related to the stigma, prejudice, stereotyping and often violence related to racism. Moreover, they are under-represented in political decision-making and therefore have few opportunities for political redress. A more subtle but equally problematic manifestation of race discrimination is through policies of assimilation, which require conformity to the dominant culture as a precondition for inclusion. In particular, national and ethnic minorities may not have the opportunity to sustain their language or culture in education or employment. ${ }^{67}$

This pattern is particularly problematic for the Roma people, who constitute the largest European minority. According to a 2011 survey by the EU Fundamental Rights agency, of the approximately 10 - 12 million Roma and related minority communities in Europe, about a third are unemployed, $20 \%$ are not covered by health insurance and $90 \%$ are living below the poverty line. For Roma, the discrimination manifested along the four axes highlighted here is particularly acute: they are highly disadvantaged; suffer from stigma, prejudice, stereotyping and violence; are both socially and politically excluded; and are clear victims of institutional structures which do not accommodate their lifestyle. As the Advisory Committee of the National Framework for Minorities put it, 'Roma are also increasingly and legitimately - calling for their rights in the fields of culture and education to be more adequately addressed. But Roma are calling louder still for states and societies to cease to treat them as a 'problem' to be resolved - the “other, who must be made to conform to mainstream society's vision of itself - and to come to grips with a more fundamental question: how to create societies that do not generate the exclusion of Roma. ${ }^{68}$

Bringing together recent case-law on race discrimination under Article 14 allows us to discern a sensitivity to several of the dimensions of the conception of substantive equality and their interactions with each other. Notably, this is frequently for the very reason that the Court needs to consider what the right to equality specifically adds to another of the substantive rights. Particularly important has been the way in which the Court has drawn on the second dimension, the recognition dimension, in order to make visible the ways in which racism transforms violence into an equality issue. This was first articulated in Nachova $v$

\footnotetext{
${ }^{67}$ Council of Europe, 'Factsheet Framework Convention for the Protection of National Minorities', available at: http://www.coe.int/en/web/minorities/fcnm-factsheet [last accessed 12 June 2015].

${ }^{68}$ Council of Europe, 'Advisory Committee on the Framework Convention: Ninth Activity Report (2012-2014)' at 12, available at: https://rm.coe.int/CoERMPublicCommonSearchServices/DisplayDCTMContent?documentId=0900001680097e c4 [last accessed 12 June 2015].
} 
Bulgaria,${ }^{69}$ where the applicants argued that prejudice and hostile attitudes towards persons of Roma origin had played a role in the deaths of two Roma men, who were shot by Bulgarian military police when they were fleeing after going absent without leave from the military. The Grand Chamber explicitly drew the connection between racial violence and stigma, prejudice and stereotyping: 'Racial violence is a particular affront to human dignity and, in view of its perilous consequences, requires from the authorities special vigilance and a vigorous reaction. ${ }^{70}$ This in turn required close attention to the fourth dimension, the need to create a society which facilitates difference and diversity: 'Authorities must use all available means to combat racism and racist violence thereby reinforcing democracy's vision of a society in which diversity is not perceived as a threat but as a source of its enrichment. ${ }^{, 71}$

Since Nachova, the Court has applied this approach to a number of cases of racist or ethnically motivated violence. In the 2015 case of Ciorcan $v$ Romania, the applicants argued that prejudice and hostile attitudes towards persons of Roma origin had led to the police using excessive force, first in serving a summons which could have been delivered by post, and subsequently in sending special force officers to deal with a crowd primarily consisting of women and children, against whom they used firearms unnecessarily. ${ }^{72}$ The Court found a breach of Articles 2 and 3 of the Convention in their procedural aspect, but went on to emphasize the ways in which an equality perspective makes us address the specific harm of racial violence. 'Treating racially-induced violence and brutality on an equal footing with cases that have no racist overtones would be turning a blind eye to the specific nature of acts that are particularly destructive of fundamental rights. Failure to make a distinction in the way situations that are essentially different are handled may constitute unjustified treatment irreconcilable with Article 14 of the Convention. ${ }^{, 73}$ A similar approach has been taken in several cases brought by Chechen nationals, who had suffered often appalling violence at the hands of the Russian authorities. ${ }^{74}$

The Court's development of substantive equality in Nachova was, however, limited by the narrow approach it took to the establishment of racist violence, requiring proof of a

\footnotetext{
${ }^{69}$ Nachova v Bulgaria, Applications Nos. 43577/98 and 43579/98, Merits, 6 July 2005 at para 144.

${ }^{70}$ Ibid. at para 145; Ciorcan v Romania, Application No. 29414/09 and 44841/09, Merits, 27 January 2015 at para 156

${ }^{71}$ Nachova, supra n 69 at para 145.

72 Ciorcan, supra n 70 at para 154

${ }^{73}$ Ibid. at para 158

${ }^{74}$ Timishev v. Russia, Application No. 55762/00 and 55974/00, Merits, 13 December 2005 at paras 56-58; Makhashevy v Russia, Application No. 20546/07, Merits, 31 July 2012 at paras 143-46; Antayev v Russia, Application No. 37966/07, Merits, 3 July 2014.
} 
particular subjective attitude on the part of the perpetrator. ${ }^{75}$ Thus, having found a breach of the right to life under Article 2, the Court held that Article 14 had not been breached in substance because it had not been established that the police would not have used the same violence against non-Roma people. Instead, the Court's focus was on the duty of investigation, holding that the State had a duty to take all reasonable steps to unmask racist motives and to establish whether ethnic hatred or prejudice played a role. In both Nachova and Ciorcan, it was held that the authorities had failed in this duty and therefore breached Article $14 .^{76}$

Nevertheless, the focus of the Court on subjective intent, and its refusal to infer race discrimination from the evidence of excessive force, severely undermines the ability of Article 14 to address disadvantage, or the first dimension. The Chamber in Nachova was willing to shift the burden of proof to the government once prima facie evidence of discrimination had been shown, but this was rejected by the Grand Chamber. Given that evidence of subjective intent is unlikely to be available to the victims, it is unfortunate that the Court simply bats the responsibility for investigating back to the very government which had blatantly omitted to do so in the face of clear evidence. Instead, the Court should have demanded that the authorities provide evidence to rebut the inference of discrimination. In Ciorcan, for example, the authorities had used thirteen police officers to serve a summons which could have been delivered by post. The Court could have required evidence that this approach to the service of summons was used in other, non-Roma cases. Instead, the government was able to rest its case on the Nachova standard, arguing that even the expression of concern by the Advisory Committee on the Framework Convention for the Protection of National Minorities about allegations of violence against Roma by Romanian law enforcement officers and the repeated failure of the Romanian authorities to remedy the situation were not sufficient to establish that racist attitudes played a role in the instant case. ${ }^{77}$ Shifting the burden of proof to require a government to explain that the treatment was not discriminatory is familiar in the field of discrimination law, having been accepted by the EU in the burden of proof directive in $1997 .{ }^{78} \mathrm{~A}$ far better approach was that in Antayev $v$ Russia where the Court found that, in the absence of any other explanation, the applicants' ethnic origin was the sole, or at least the decisive, reason for the involvement of a special police

\footnotetext{
${ }^{75}$ Nachova , supra n 69 at para 157.

${ }^{76}$ Ibid. at para 168.

${ }^{77}$ Ciorcan v Romania, supra n 70 at para 155; see also Moschel, 'Is the European Court of Human Rights' Case Law on Anti-roma Violence 'Beyond Reasonable Doubt?' (2012) 12 Human Rights Law Review 479

${ }^{78}$ Council Directive 97/80/EC on burden of proof in cases of discrimination based on sex (1998) OJ L 14.
} 
service in a search conducted within an investigation of a minor offence. ${ }^{79}$ In that case, there was well-documented racist verbal abuse of the applicants, together with recurrent reference to internal police instructions to treat suspects of Chechen origin in a particular manner. ${ }^{80}$ However, although Antayev was mentioned in Ciorcan, the Court reverted to its position in Nachova. This return to a focus on subjective intent rather than on the disadvantage caused constitutes a serious regression for the developing notion of substantive equality. As will be seen below, this contrasts with its approach to gender-based violence, when it has not insisted on proof of intention.

A separate set of cases tested the Court's approach to the role of participation, or the third dimension, and its interaction with respect for and accommodation of difference, the fourth dimension. The arena for challenge was the consociational compromise reached in Bosnia and Herzegovina, after the bloody civil war. It was agreed that the second chamber of the State parliament (the House of Peoples) would consist of equal numbers of each of the three main ethnic groupings or 'constituent peoples' (Bosniacs, Croats and Serbs). In addition, a collective Presidency would consist of one member each of the constituent peoples. ${ }^{81}$ Those who did not belong to any of the three groups were ineligible to stand for election to either of these institutions. In Sejdić and Finci v. Bosnia and Herzegovina ${ }^{82}$, this arrangement was challenged by two members of minority groups, one Jewish and one Roma. The government argued that the ultimate goal of the constitutional structure was to establish peace and dialogue between the three main ethnic groups, and that the time was not yet ripe for a political system which simply reflected majority rule. ${ }^{83}$ In this sense, it raised the fourth dimension, recognising difference, as a defence to the third dimension, participation. The Court, however, had no doubt that this was not a good enough justification, whether or not it had initially been so. It did not reject power-sharing entirely, implicitly recognising the importance of accommodating difference. However, it was held that Article 14 was breached because it was possible to devise mechanisms of power sharing which did not automatically lead to the exclusion of members of some communities. In other words, accommodating difference should not be at the expense of participation for some groups.

\footnotetext{
79 Ciorcan, supra n 70 para 166; Antayev, supra n 74 at para 127.

${ }^{80}$ Antayev, supra n 74 at para 127; see also Ciorcan, supra n 70 at para 166.

${ }^{81}$ Based on self-identification through declaration of affiliation.

82 Sejdić and Finci, supra n 51.

${ }^{83}$ Ibid. at para 24. See also Zornić v. Bosnia and Herzegovina, Application No 3681/06, Merits, 15 July 2014.
} 
The importance of addressing all the dimensions of equality has also been highlighted in the Roma school segregation cases. The widespread practice in many European countries of segregating Roma children into separate schools or classes is challenging because it is often defended on the grounds that the children have special needs or are unfamiliar with the dominant language. This looks like a pursuit of the fourth dimension, that is, accommodating difference. However, a closer look shows that in fact such schooling is frequently of a vastly inferior character. Once the claim of special treatment is set against the need to redress disadvantage, or the first dimension, it becomes obvious that this is not truly a transformative strategy, but a cover for perpetuating disadvantage. In $\mathrm{DH} v$ Czech Republic, the Court put the need to redress disadvantage centre stage, drawing on statistics showing extensive segregation into inferior schools to reject the Government's claim that it was providing for special needs. This was made even more explicit in Orsus, where the Government argued that the reason for the segregation was Roma children's poor knowledge of Croatian. The Court accepted that in certain circumstances, such placement might 'pursue the legitimate aim of adapting the education system to the specific needs of the children.' This would be true to the transformational dimension of substantive equality. However, it found that no measures were in place in the schools in question to teach the Roma children Croatian with the aim of transferring them to integrated education. In this sense, despite claiming to fulfil the transformative dimension, it in fact breached the redistributive dimension. The recognition dimension or the stigmatising effect of segregation received less explicit attention. Although it was raised and rejected in the domestic proceedings, the Grand Chamber did not specifically deal with this aspect of substantive equality. This can be compared with the seminal case on school segregation in the US, Brown $v$ Board of Education. ${ }^{84}$ In rejecting the claim of 'separate but equal', the US Supreme Court in Brown regarded the stigmatising effect of segregation as crucial. Even if educational facilities were allegedly of the same quality, the stigma attached to compulsory segregation would lead to lack of self esteem which would in turn deepen the disadvantage experienced by African Americans.

Nevertheless, Brown did not go far enough in embracing the transformative dimension of equality, assuming as it did that simply assimilating African American learners into formerly white schools would solve the problem of racism. As is now acknowledged, it would be necessary in addition to institute changes in the structure of the white schools to

\footnotetext{
${ }^{84}$ Brown v Board of Education 347 U.S. 483 (1954) (US Supreme Court).
} 
value and incorporate the culture and identity of the newcomers. ${ }^{85}$ The issue of genuine transformation remains challenging too in the context of segregation of Roma pupils. The Court has on several occasions recognised the need for specific measures to include Roma people without requiring them to assimilate. ${ }^{86}$ Thus in Orsus, the Court stated: 'The vulnerable position of Roma/Gypsies means that special consideration should be given to their needs and their different lifestyle both in the relevant regulatory framework and in reaching decisions in particular cases. ${ }^{87}$ However, the Court has not built this insight into its reasoning or its remedies. In practice, there has been little change in the intensity of segregation of Roma children in many countries in Europe, including the Czech Republic and Croatia.

The race discrimination cases dealt with here have also raised the question of the role of choice in relation to Article 14. As argued above, substantive equality requires careful scrutiny of claims that the situation the applicant finds herself in is a result of her own choice, since in many situations, such choice is heavily constrained by the very factors contributing to her disadvantage, stigma and lack of participation. The Court has largely followed this line of reasoning. In DHv Czech Republic, the State argued that there was no breach of Article 14, since the parents had agreed to separate education. At first instance, the Chamber accepted this argument. From a substantive equality perspective, as was argued above, while parental agreement may look as if it fulfils the participatory dimension, the combination of participation and the need to redress disadvantage makes it clear that voice and agency need to be assessed in light of power imbalances. The Grand Chamber, overturning the Chamber decision reflected this approach. Thus it stated: 'In the circumstances of the present case, the Court is not satisfied that the parents of the Roma children, who were members of a disadvantaged community and often poorly educated, were capable of weighing up all the aspects of the situation and the consequences of giving their consent. ... ${ }^{88}$ Moreover, even if they were capable of doing so 'no waiver of the right not to be subjected to racial discrimination can be accepted, as it would be counter to an important public interest. ${ }^{89}$

The political settlement in Bosnia and Herzegovina also required the Court to address the role of choice within the equality analysis. In Zornić v. Bosnia and Herzegovina, the

\footnotetext{
${ }^{85}$ Minow, In Brown's Wake (2010).

${ }^{86}$ Chapman v United Kingdom, Application no. 27238/95, Merits, 18 January 2001, Connors, supra n 32.

${ }^{87}$ Oršuš v Croatia, Application no. 15766/03, Merits, 16 March 2010.

${ }^{88} \mathrm{DH}$, supra $\mathrm{n} 29$ at para 203. .

${ }^{89}$ Ibid. at para 204.
} 
applicant was ineligible for election to the House of Peoples or the collective head of State because she did not declare affiliation with any of the constituent people. This was not because she belonged to an ethnic minority, but because she regarded herself as simply a citizen of Bosnia and Herzegovina. The Government argued that the applicant 'chose of her own will not to declare affiliation with any of the "constituent people". She could change her mind at any time should she wish to participate in the political life of Bosnia and Herzegovina.' 90 The Court made short shrift of this argument. Whatever the reasons for not declaring affiliation, 'the Court considers them in any case irrelevant. The applicant should not be prevented from standing for elections for the House of Peoples on account of her personal self-classification. ${ }^{91}$

\section{Gender}

Like race, gender inequality in Europe can be mapped along the four axes identified above. Women remain at a significant disadvantage in the paid workforce, as evidenced by the persistence of gender pay gap, segregation of women into lower paying work, a predominance of women in low paid and precarious work, and a significant 'motherhood penalty.${ }^{92}$ Behind this lies the largely unchanged division of work in the home. Although women increasingly participate in the paid workforce, they remain primarily responsible for unpaid reproductive, caring and domestic work. ${ }^{93}$ Thus disadvantage in the paid labour force derives in many respects from the ascription to women of reproductive roles. In particular, undervaluation of women's work is a direct result of the impact on socio-economic status of stereotyping or recognition harms. The recognition dimension is also manifested through the ways in which sexual stereotypes contribute to women's labour force disadvantage, whether through sexual harassment at work or the risk of violence in accessing workplaces. These factors in turn contribute to and are reinforced by women's relative lack of voice, whether in collective organisation through trade unions in the workforce, or on company boards or in the political arena. This brings in the third dimension, the participatory dimension. Addressing these three dimensions alone will not, however, have lasting effects without changing the underlying structures which perpetuate these patterns. This is where the fourth,

\footnotetext{
90 Zornić supra n 83 at para 25.

91 Ibid. at para 36.

92 European Commission, 'Commission Recommendation on pay transparency and the gender pay gap Frequently Asked Questions’ 9 March 2014. available at: http://europa.eu/rapid/press-release_MEMO-14160_en.htm [last accessed 12 June 2015].

${ }^{93}$ European Commission, 'Childcare: Commission calls on Member States to do more’ 3 June 2013, available at: http://europa.eu/rapid/press-release_IP-13-495_en.htm [last accessed 12 June 2015].
} 
transformative dimension, comes into play, requiring foundational change in the ways in which the boundaries between paid and unpaid work are configured in labour law, and in the gendered roles ascribed to men and women in each of these spheres.

Although the paid labour force is the locus of much of women's inequality, the structure of the ECHR is not immediately facilitative for dealing with discrimination at work. There is no express right to work, and Convention rights are directed against the States so that private employers are not directly bound by the Convention. Even for State employees, there are important reservations. The right to be recruited to the civil service was deliberately omitted from the Convention, and restrictions can be placed on the right to freedom of assembly and association in relation to members of the administration of the State. ${ }^{94}$ However, in an important recent development, the ECHR has held that sex discrimination at work can fall within the ambit of Article 8, therefore triggering the applicability of Article 14. In Emel Boyraz v Turkey, as we have seen, the Turkish civil service refused to appoint a woman to a post as security officer on the grounds that she was a woman. The Court held that the concept of 'private life' extends to aspects relating to personal identity, of which sex is an inherent part. The judgment is a clear example of the Court's appreciation of the need to draw the link between the different dimensions of equality in order to deal with it properly. By utilising Article 8, the Court was able to characterise work as centrally affecting both a person's material well-being and her sense of self-esteem and relations with others. Thus the Court stated that a measure 'as drastic as a dismissal from a post on the sole ground of sex has adverse effects on a person's identity, self-perception and self-respect and, as a result, his or her private life.' In addition, her dismissal 'had an impact on her “inner circle” as the loss of her job must have had tangible consequences for the material well- being of her and her family. The applicant must also have suffered distress and anxiety on account of the loss of her post. What is more, the applicant's dismissal affected a wide range of her relationships with other people, including those of a professional nature and her ability to practise a profession which corresponded to her qualifications. ${ }^{95}$ Having held that the dismissal fell within the ambit of Article 8, the Court had no difficulty in finding that the purported explanation for refusing to allow women to perform the role of security officer was not founded on any facts. ${ }^{96}$ This is then a clear example of stereotyping and prejudice, or the recognition dimension, causing socio-economic disadvantage, in the form of denial of a job.

\footnotetext{
${ }^{94}$ Article 11(2) ECHR; Vogt v. Germany, Application no. 17851/91, Merits 26 September 1995.

95 Boyraz, supra n 18 at para 44; see however the partially dissenting judgement of Judge Spano.

96 Ibid. at para 54.
} 
At the same time, the Court's use of Article 8 makes it clear that the interaction also works in the opposite direction: that is, the loss of a job can cause further recognition harms.

The Court has also made progress towards substantive equality in relation to parenting rights. For many years, women have struggled to achieve protection against discrimination on grounds of pregnancy and the right to paid maternity leave. This addressed primarily the first dimension, namely the need to redress disadvantage. But it did not go far enough bring about structural change, the fourth dimension. This was because, by giving parenting rights exclusively or predominantly to women, this approach risked reinforcing women's primary responsibility for child-care. A transformative approach, bringing about real substantive equality, would require that men be afforded the same rights as women. Until recently, the Court had been very tentative in this respect, waiting as it is wont to do for a European consensus to emerge. ${ }^{97}$ But in Markin it held that the provision of maternity leave to mothers not fathers had the 'effect of perpetuating gender stereotypes disadvantageous both to women's careers and to men's family life' ${ }^{98}$ In this case, a Russian serviceman who was responsible for his children claimed equal parenting rights as a woman. In civilian life, both men and women enjoyed equally generous parenting rights; but the Russian government argued that the need for combat effectiveness made it impossible to do the same for men in the military. In upholding the father's claim, the Court clearly drew together the relevant dimensions of substantive equality. In this way, the ECtHR is moving in step with the EU. ${ }^{99}$

Similarly significant progress has been made towards a multi-dimensional understanding of substantive equality in relation to gender-based violence (GBV). GBV has only relatively recently been recognised as an equality issue. Once seen through the prism of substantive equality, however, there is no doubt as to this connection. Condoning violence against women on the grounds that it happens within the family or in private space, or refusing to believe women's accounts of such violence, reflect a deep-seated negation of women as persons, the antithesis of recognition. This in turn both stems from and reinforces gendered power relations in society. This specifically gendered understanding was captured in CEDAW's watershed General Recommendation No. 19 in 1992. The General Recommendation is particularly perspicacious is the way in which it characterises GBV in

\footnotetext{
${ }^{97}$ Petrovic v Austria supra n 35.

${ }^{98}$ Markin v Russia (2013) 56 E.H.R.R. 8 (European Court of Human Rights)

${ }^{99}$ C-104/09 Roca Álvarez v Sesa Start España ETT SA [2010]1 ECR I-08661;Fredman, 'Reversing roles: bringing men into the frame' (2014) 10 International Journal of Law in Context 442-459; see also Timmer, 'Toward an Anti-Stereotyping Approach for the European Court of Human Rights' (2011) 11 Human Rights Law Review707.
} 
terms of the interaction between all four dimensions of substantive equality highlighted above. First and foremost, it captures GBV as stemming from stereotyped roles whereby women are regarded as subordinate to men, which perpetuate and even justify family violence and abuse, forced marriage, dowry deaths, acid attacks and female circumcision. This in turn leads to disadvantage in the context of the other dimensions. The physical and mental consequences help to maintain women in subordinate positions, and contribute to lower levels of education, skills and work opportunities. Similarly, women’s political participation is affected. To bring about real substantive equality, all these dimensions need to be addressed in an interactive form.

This approach to GBV can now also be discerned in recent ECHR case law. In Opuz $v$. Turkey, ${ }^{100}$ after a long history of appalling violence against the applicant and her mother, the applicant's partner shot his mother-in-law dead. The applicant and her mother had filed complaints against him since 1995, but the authorities had repeatedly failed to provide sufficient protection. The ECtHR was able to draw extensively on international law sources to hold that the State's failure to give women appropriate protection against GBV constituted sex discrimination. Particularly importantly, in addition to finding a breach of the right in Article 3 not to be subjected to torture or inhuman treatment or punishment, the Court was prepared to go further and find a breach of Article 14. The Court's approach shows a real sensitivity to the need to understand gender equality in a multi-dimensional way. Most important was its emphasis on the ways in which stigma, stereotypes and prejudice against women can lead the authorities to refuse to recognise the victims as worthy of State protection and to the passive or active condoning of perpetrators' actions. The Court was also sensitive to the interaction between the harms of recognition and redistribution. It emphasised the high incidence of domestic violence in the victim's region, with the majority of the victims being Kurdish women, with little education and no independent source of income. Thus the fact that the women at risk were already some of the most disadvantaged in Turkey aggravated and reinforced the stereotypical view of women as being in a subordinate position to men and therefore worthy of lower protection. Unlike the racist violence cases above, it is also significant that the Court's application of Article 14 was in terms of disparate impact, particularly the absence of a requirement of proof of intention and the acceptance of statistics produced by the applicant and uncontested by the State to establish a pattern of discrimination. This situated the particular hardship of the individual applicant in the context

${ }^{100}$ Opuz v Turkey, Application No. 33401/02, Merits, 9 June 2009. 
of much wider patterns of gender based violence in Turkey generally and in the applicants' district particularly. Similarly, the police’s dismissive attitude towards the victims’ complaints against their husbands or other male perpetrators was part of a generalised refusal, also documented in the two reports presented by the applicants, to recognise that such violence was unacceptable, whether in the private or public sphere.

GBV fundamentally challenges conventional assumptions requiring respect for family and the public private divide. This brings in the fourth dimension, the need for structural change. The Turkish Government argued that, since the applicants had withdrawn their complaints on several occasions, any further intervention would constitute a breach of the victims' Article 8 rights to respect for family and private life. The Court roundly rejected this argument. In the earlier domestic violence case of Bevacqua and S. v. Bulgaria, ${ }^{101}$ it had already rejected the authorities' view that the dispute was a 'private matter' so that no assistance was required. This, the Court held, would have been incompatible with the State's positive obligations to secure the enjoyment of the victims’ rights. In Opuz, the Court reiterated that in cases such as this, interference with the private or family life might be necessary to protect health and the rights of others. ${ }^{102}$

Opuz was followed swiftly by Eremia v Moldova. Here too the Court held not only that the State's failure to protect the victims against domestic violence was a breach of its positive duties under Article 3, but also constituted a breach of Article 14. Significantly, the Court now regarded it as established that 'the State’s failure to protect women against domestic violence breaches their right to equal protection of the law and that this failure does not need to be intentional. ${ }^{, 03}$ Again, the Court highlighted the ways in which stereotypes and prejudices against women permeated the State's attitude to victims of violence and therefore entrenched their disadvantaged position, particularly in the context of a severe imbalance of power within the family. A key piece of factual evidence cited by the Court in supporting its conclusion in the applicant's favour was the fact that the relevant family protection department in her area had failed to enforce the protection order issued in her name for over three months, and had allegedly suggested reconciliation, since she was "not the first nor the last woman to be beaten up by her husband." ${ }^{104}$ Moreover, the State Prosecutor had decided to suspend all proceedings again the perpetrator for a year, although

\footnotetext{
101 Bevacqua and S. v. Bulgaria, Application No. 71127/01, Merits, 12 June 2008 at para 83.

102 Opuz, supra n 100.

${ }^{103}$ Eremia v Moldova, Application No 3564/11, Merits, 28 May 2013 at para 85; citing ibid at para 191.

104 Ibid. at para 87.
} 
the latter admitted to having physically and psychologically abused three members of his family. This was because this was considered a 'less serious offence', and the perpetrator was well respected at work and in the community and 'did not represent a danger to the society. ${ }^{105}$ As in Opuz, the Court situated this incident in the context of a wider institutional attitude condoning domestic violence against women. It referred specifically to the findings of the UN Special Rapporteur, which highlighted the ways in which patriarchal attitudes have not only increased women's vulnerability to violence and abuse, but also meant that it was condoned by society. Domestic violence was perceived as a form of family conflict and not a problem warranting legal intervention, or even recognised as such by officials, society and women themselves. ${ }^{106}$ In the result, the Court found that 'The combination of the above factors clearly demonstrates that the authorities' actions were not a simple failure or delay in dealing with violence against the first applicant, but amounted to repeatedly condoning such violence and reflected a discriminatory attitude towards the first applicant as a woman., ${ }^{107}$

As in the race cases, the GBV cases required the Court to address the role of choice in relation to substantive equality. In both Opuz and Erudemia, the Government argued that the applicants had withdrawn charges against the perpetrator and therefore there was good reason for not pursuing the complaint. As argued above, substantive equality requires genuine participation and voice, and the interaction between the participative dimension and the disadvantage dimension means that choices are not automatically regarded as an exercise of participation or agency. This approach was endorsed by the Court in both cases. In Opuz, the Court placed great weight on the fact that there was no indication that the authorities considered the motives behind the withdrawal of the complaints, despite the fact that the applicant's mother had told the Public Prosecutor that she and her daughter had withdrawn their complaints because of death threats issued against them by the perpetrator. ${ }^{108}$ The Court noted that there was no overall consensus among contracting states as to whether to pursue criminal proceedings once a complaint has been withdrawn. Nevertheless, it was alive to the real likelihood, as was argued in both cases, that the complaints were withdrawn under severe pressure, including threats of violence. It therefore held that 'the more serious the offence or the greater the risk of further offences, the more likely that the prosecution should

\footnotetext{
105 Ibid. at para 27.

${ }^{106}$ Cited in ibid. at para 21

${ }^{107}$ Eremia, supra n 104 para 89.

${ }^{108}$ Opuz, supra n 101para 143.
} 
continue in the public interest, even if victims withdraw their complaints. ${ }^{\text {, }}{ }^{109}$ It reached a similar conclusion in Erudemia.

\section{Sexual Orientation and Transgender}

For LGBT people in Europe, the dimension of inequality which is most pronounced is the recognition dimension, namely stigma, stereotyping, prejudice and violence. However, this centrally implicates the other axes. Harassment and bullying at school and at work can have serious implications for progress in the workforce, leading to economic disadvantage. LGBT people are generally small minorities on the political scene, making it difficult for their voice to be heard through democratic processes. Moreover, rather than celebrating and accommodating difference, social structures require LGBT people to cover or hide their identity and relationships; this itself leads to social exclusion or marginalisation. This is compounded for same-sex relationships. Failure to recognise LGBT relationships leads to further recognition harms, particularly in relation to parenting rights, whether through custody, adoption or surrogacy. It also leads to material disadvantage, including in relation to pensions, benefits, or housing.

The earlier ECHR cases characterised the issue as one of privacy under Article 8 rather than equality. Thus the criminalisation of homosexual relations between adults ${ }^{110}$ and the discharge of homosexuals from the armed forces, ${ }^{111}$ were found to be breach of Article 8 alone. More recently, Article 14 has also come into play. ${ }^{112}$ As we have seen, the Court has held that discrimination on grounds of sexual orientation is 'undoubtedly covered' by Article $14,{ }^{113}$ and that only very weighty reasons could justify any differentiation on this ground. ${ }^{114}$ Indeed, distinctions based solely on sexual orientation are unacceptable. ${ }^{115}$ In determining the meaning of equality in these contexts, the Court has taken some important steps towards a substantive approach, in particular through its appreciation of the ways in which stigma and prejudice have implications in relation to disadvantage and social and political exclusion. However, it has thus far stopped short of a truly transformational approach by failing to require the recognition of same-sex marriage.

\footnotetext{
${ }^{109}$ Ibid. at 139.

${ }^{110}$ Dudgeon v UK, Application No. 7525/76, Merits, 2 October 1981.

111 Smith and Grady v UK, (Applications nos. 33985/96 and 33986/96), Merits, 27 September 1999.

${ }^{112}$ L. and V. v. Austria, Application No. 39392/98 and 39829/98, Merits, 9 January 2003.

113 Salgueiro da Silva Mouta, supra n 19.

${ }^{114}$ EB, supra n 11 ; Smith and Grady, supra n 111.

115 Salgueiro da Silva Mouta, supra n 19; EB, supra n 11.
} 
Its primary contribution towards a substantive approach has been along the recognition axis, as reflected in its acceptance that the relationship of 'a cohabiting same-sex couple living in a stable de facto partnership falls within the notion of family life, just as the relationship of a different-sex couple in the same situation would. ${ }^{\text {116 }}$ The recognition dimension has been held to have intrinsic value, whether or not it leads to material disadvantage. In Vallianatos v Greece, the Court rejected the Greek government's argument that same-sex couples lost nothing in legal terms by being barred from entering into civil partnerships available to opposite sex couples. Instead, the Court stressed, 'the civil partnerships provided for by [the relevant law] as an officially recognised alternative to marriage have an intrinsic value for the applicants irrespective of the legal effects, however narrow or extensive, that they would produce.' ${ }^{117}$ At the same time, the Court has been vigilant in relation to the need to redress disadvantage caused by failure to recognise same sex relations. Thus in $P B v$ Austria, the refusal to extend one partner's accident and insurance cover to the other was held to be a breach of Article 14 with Article $8 .{ }^{118}$ Similarly, the Court has gradually reversed its own case law to hold in favour of granting of parental rights ${ }^{119}$ and the right to adopt a child. ${ }^{120}$ It has taken one step towards requiring structural change in the most recent decision of Oliari $v$ Italy, where it held that the Italian government had breached their positive duty under Article 8 by failing. to provide a form of recognised civil partnership. $^{121}$

However, the Court has thus far refused to take the further step towards transformation and hold that States are required to recognise same-sex marriage. Although in Schalk, the Court found that the right to marry in Article 12 need not always be limited to persons of the opposite sex, it held that Article 12 could not be construed as imposing an obligation on Contracting States to allow same-sex marriage. This was reiterated in Hämäläinen and Oliari, both very recent cases. In Schalk and Oliari, the court also rejected the possibility that this result could be achieved by reading Article 14 together with either Article 8 or Article 12. Its chief reason was that there was not yet sufficient consensus: at the time of the Vallianatos decision, only nine Council of Europe states provided for same-sex

\footnotetext{
${ }^{116}$ PB and JS v Austria, Application No. 18984/02, Merits, 22 July 2010 at para 30. See also Schalk and Kopf v Austria (2011) 53 EHRR 20 (ECHR) para 94; Vallianatos v Greece, Applications No 29381/09 and 32684/09, Merits, 7 November 2013 at para 73.

117 Vallianatos, supra n 116 at para 81.

${ }^{118}$ PB and JS, supra n 116; see also Karner v Austria , Application No. 40016/98, Merits, 24 July 2003.

119 Salgueiro da Silva Mouta, supra n 19.

120 Ibid. Fretté v France, Application No. 36515/97, Merits, 26 February 2002.

121 Oliari, supra n 6.
} 
marriage. The applicants in Oliari argued that since Schalk, many more countries had legislated in favour of gay marriage, and many more were in the process of discussing the issue. Given that the Convention was a living instrument, they urged the Court to redetermine the position. The Court, however, held that despite the gradual evolution of States on the matter (11 Council of Europe states recognised gay marriage at the time of the judgment), the earlier cases remained relevant. Moreover, despite the submission by the applicants that it was stigmatising to be shut out of the institution of marriage, the Court held that Article 14, in conjunction with either Article 9 or Article 12, could not be interpreted as imposing an obligation on States to recognise same sex marriages.

It is true that at the time of the Convention, this was undoubtedly the way the provision was understood, but the Court has consistently held that the Convention should be interpreted as a living instrument. The second applicants' argument that the Court should do more than simply reflect existing consensus, but follow its own example in the early case of Goodwin and set the trend. While it is likely, given current trends, that there will eventually be sufficient consensus in favour of marriage, at present the Court is eschewing the transformative dimension, thereby falling short of a fully substantive approach to equality in this context.

This resistance to taking a fully transformative approach has spilled over into the Court's treatment of equality for transsexual people. In Hämäläinen v. Finland, ${ }^{122}$ the applicant was born male and married and had a child before transitioning to living as a woman. After her gender reassignment surgery, she was refused the right to change her male identity number to a female. This was because under Finnish law, a person's new gender could not be registered unless they were unmarried or their spouse gave consent to transform their marriage into a registered partnership. The applicant and her wife did not want to end their marriage or turn it into a registered partnership, although the legal sequeli of the latter were the same as the former. She argued that she had been treated less favourably than cissexuals, who obtained legal gender recognition automatically at birth and did not run the risk of 'forced divorce' in the way that her marriage did. The Grand Chamber held that the case fell within the notion of private and family life for the purposes of Article 8. However, it held that her situation was not sufficiently similar to cissexuals for her to be able to claim to

${ }^{122}$ Hamalainen, supra n 11. 
be in the same situation as cissexuals. ${ }^{123}$ The claim under both Articles 8 and 14 were therefore rejected.

This brisk reversion to a formal understanding of equality as requiring that likes be treated alike is surprising in the light of the progress towards substantive equality seen in the other cases reviewed here. Indeed, in earlier cases, the Court had endorsed the recognition dimension, reversing previous case-law to hold that discrimination against transsexual people was discrimination on grounds of sex. ${ }^{124}$ Although the Court has frequently stated that discrimination under Article 14 entails differential treatment of two otherwise similarly situated individuals, it is rare for the Court to reach its conclusion simply on the basis that the situations are not sufficiently similar. Moreover, it gave no reasons why transsexuals' situation was not regarded as sufficiently similar to cissexuals, nor who the Court would have regarded as appropriate comparators. On a substantive view of equality, by contrast, there was a clear breach of both the redistributive and recognition dimensions. The requirement that a marriage be dissolved applied only to individuals who had transitioned from one gender to another and the applicant was therefore clearly disadvantaged because of her transsexuality. This had severe implications for the recognition dimension, because her formal identity remained male and could not be changed. The real problem in Hämäläinen was that the Court's reluctance to engage with the transformative dimension forced it to ignore the distributive and recognition dimensions. Indeed, the Chamber admitted that one of its main motivations was the concern that to allow the applicant to remain married would in effect be requiring Finland to permit same-sex marriages, contradicting its very recent decision in Schalk.

\section{E. Disability}

As in the other strands, disability discrimination reflects the interaction between the different dimensions of substantive equality. Disability, more expressly than any other ground, requires an asymmetric approach which focuses on redressing disadvantage rather than same treatment. According to the ILO, a person with a moderate disability in Europe aged between 16 and 64 has only a $47 \%$ chance of finding a job, falling to $25 \%$ for a person with a severe

\footnotetext{
123 Ibid. at para 112.

${ }^{124}$ Goodwin v UK, Application No. 28957/95, Merits, 11 July 2002.
} 
disability. ${ }^{125}$ This is partly due to the widespread and severe stigma and prejudice against persons with disabilities, whether inside or outside the labour market. Moreover, violence against persons with disabilities is widely underestimated and ignored. ${ }^{126}$ At the same time, measures aimed at redressing disadvantage on account of disability are often themselves stigmatic and patronising. Rather than rights-bearers, persons with disabilities have been seen to require welfare, protection or charity. The approach to the first dimension, redressing disadvantage, therefore needs to be permeated with a commitment to the second, countering stigma and stereotyping. This feeds back to the ways in which disadvantage based on disability is characterised. A medical model of disability assumes that disability is entirely constituted of personal characteristics, rather than being a response to environmental barriers and preconceptions. The social model, by contrast, insists that the disabling effects of the environment need to be recognised and addressed. This means that the fourth dimension, the need for structural change, has become central to the equality framework for persons with disabilities, usually in the form of duties of reasonable accommodation or adjustment. Structural change should not, again, reinforce stigma but instead emphasise that ability and disability lie on a spectrum. As the UN Ad Hoc Committee on the Rights of Persons with Disabilities put it: 'Disability is a normal aspect of life; all kinds of disabilities can happen to all types of people at all stages in their normal lifecycles. ${ }^{127}$ Similarly, Bickenbach et al have argued for an approach that 'respects difference and widens the range of the normal'. ${ }^{128}$ Also central is the participative dimension. There is a widespread pattern of failing to consult or involve people with disabilities, even in relation to decisions which affect them personally, but also in the wider political arena. In addition, a key aspect of substantive equality for persons with disabilities is to counter social exclusion. Thus the particular disadvantage experienced by people with disabilities is a result of a close interaction between all four dimensions: the lack of structural change or accommodation turns the environment into a disabling one, which entrenches disadvantage, which in turn both causes and is caused by stigma and stereotyping and lack of meaningful participation.

\footnotetext{
${ }^{125}$ Cited by Clifford 'The UN Disability Convention and its impact on European equality law' (2011) 6 Equal Rights Review 13

126 Ibid.

${ }^{127}$ UN Ad Hoc Committee on a Comprehensive and Integral International Convention on Protection and Promotion of the Rights and Dignity of Persons with Disabilities, 'Issues and Emerging Trends Related to Advancement of Persons with Disabilities' 16-17 June 2003 A/AC.265/2003/1 at paras 9-10.

${ }^{\mathbf{1 2 8}}$ Bickenbach and others, 'Models of Disablement, Universalism and the International Classification of Impairments, Disabilities and Handicaps' (1999) 48 Journal of Social Science and Medicine 1173 at 1182.
} 
Disability discrimination has been increasingly framed in a multi-dimensional way, in particular by the Convention on the Protection of Rights of persons with Disabilities (CRPD). ${ }^{129}$ The CRPD gives core emphasis to stigma, stereotyping and violence, with specific provisions requiring States to affirm that persons with disabilities have the right to recognition as persons before the law, ${ }^{130}$ and to take appropriate measures to protect persons with disabilities from violence and abuse. ${ }^{131}$ Similarly, the participative dimension is key: the CRPD requires State Parties to 'closely consult with and actively involve persons with disabilities' in the development and implementation of legislation and policies relating to disability. ${ }^{132}$ The definition of disability in the CRPD emphasises the interaction between impairment and social barriers, ${ }^{133}$ and therefore requires a central focus on the fourth dimension, the need for structural change. Thus Article 5(3) requires States Parties to take all appropriate steps to ensure that reasonable accommodation is provided to ensure that persons with disabilities can enjoy their rights on an equal basis with others. ${ }^{134}$ The EU employment framework directive similarly requires reasonable accommodation to enable a person with a disability to have access to, participate, or advance in employment. ${ }^{135}$

There have only been a handful cases on disability under Article 14; most of the disability cases have been dealt with under other Articles. ${ }^{136}$ Thus it was not until Glor v Switzerland that the Court explicitly included disability within the category of 'other status' and therefore protected under Article 14. ${ }^{137}$ This has been followed by Kiyutin $v$ Russia, which included HIV/AIDS status within the scope of Article 14, and Kiss, which referred to people with mental illness. Nevertheless, the case law contains some important resonances for a substantive equality approach. In all three cases, the Court has been sensitive to the ways in which prejudice and stereotype can create disadvantage, leading to both social and political exclusion. This can be seen primarily in the formulation and application of the justification defence. As formulated in Kiss: 'If a restriction on fundamental rights applies to a particularly vulnerable group in society, who have suffered considerable discrimination in

\footnotetext{
${ }^{129} \mathrm{~A} / \mathrm{RES} / 61 / 106$.

${ }^{130}$ Ibid. at Article 12.

${ }^{131}$ Ibid. at Article 16.

132 Ibid. at Article 4(3).

133 Ibid. at Article 1.

134 See definition in ibid at Article 2.

${ }^{135}$ Article 5, Council Directive 2000/78/EC, establishing a general framework for equal treatment in employment and occupation (2002) OJ L 303.

${ }^{136}$ For a useful summary, see European Court of Human Rights-Press Unit, 'Fact Sheet -Persons with disabilities and the ECHR' March 2015, available at: http://www.echr.coe.int/Documents/FS_Disabled_ENG.pdf [last accessed 12 June 2015].

137 Glor, supra n 23.
} 
the past, then the State's margin of appreciation is substantially narrower... The reason for this approach, which questions certain classifications per se, is that such groups were historically subject to prejudice with lasting consequences, resulting in their social exclusion.' ${ }^{138}$

Each of these three cases gives specific emphasis to one of the dimensions. The role of stigma, stereotyping and prejudice and its ability to aggravate disadvantage was particularly highlighted in the HIV/AIDS case, Kiyutin. In this case, the applicant, an Uzbeki national, had married a Russian woman and settled in Russia. When he applied for a residence permit, he was required to undergo testing for HIV and was found to be positive. For this reason, he was refused a residence permit and subsequently faced deportation. Since non-Russian nationals resident in Russia had no entitlement to free medical assistance, there was no risk that he would represent a financial burden on the Russian health-care system. ${ }^{139}$ The Court held that there had been a breach of Article 14, taken together with Article 8. People living with HIV/AIDS clearly fitted the criteria for strict scrutiny set out in Kiss, being a particularly vulnerable group which was historically subject to prejudice with lasting consequences, resulting in social exclusion. The Court emphasized the widespread stigma and exclusion of people living with HIV/AIDS in the Council of Europe region. ${ }^{140}$ Moreover, because HIV/AIDS was often associated with particular groups, such as sex workers, gay people and drug users, these groups were doubly stigmatised. The State had argued that the exclusion was for public health reasons. This too, the Court held, was based on stereotyping and prejudice, since it was well documented by experts in the field that travel restrictions on people living with HIV could not be justified by public health concerns. ${ }^{141}$ In countering this stigma, the Court stressed, it was crucial to have individualised evaluation. ${ }^{142}$

It was the participatory dimension which was the entry point in Kiss, which concerned the Hungarian rule excluding all people under full or partial guardianship from the right to vote. The applicant, who suffered from bipolar disease, was excluded from the voters' role. He claimed that this was a breach of both Article 3 Protocol 1 (right to free elections) and Article 14. This has important ramifications: recent figures for the EU alone show that in 17 out of $27 \mathrm{EU}$ member states, persons with mental health problems and those with intellectual

\footnotetext{
${ }^{138}$ Kiss, supra n 31 at para 42.

${ }^{139}$ Kiyutin, supra n 20 at para 70.

140 Ibid.at para 64.

141 Ibid. at para $67-8$.

142 Ibid. at para 74.
} 
disability are excluded from political participation or are permitted only limited political participation. ${ }^{143}$ In the event, the Court decided the case on the basis of Article 3 Protocol 1; but it incorporated many of the insights from Article 14 into this reasoning. It held that a generalised exclusion from voting, without judging individual capacities, was a breach of Article 3 Protocol 1. This brought together three of the dimensions by showing the ways in which the ways in which prejudice and stereotype can create disadvantage, leading to both social and political exclusion.

The Court's jurisprudence on the transformative dimension is, however, underdeveloped, and it has not established an express conception of reasonable accommodation. Indeed, in the earlier case of Botta $v$ Italy, the Court rejected the complaint that, by allowing a private beach to remain un-adapted for persons with disabilities, Italy was in breach of Articles 8 and 14. Italian law did in fact require such beaches to be adapted; so that the complaint was against the failure to enforce the law. Although taking a broad view of the right to respect for private life to include interpersonal relations, the Court held that the right to gain access to the beach and sea during the claimant's holidays concerned interpersonal relations of 'such broad and indeterminate scope' that there could be no link between his private life and the State's responsibility to ensure compliance with the duty of accommodation. ${ }^{144}$ Nor was it prepared to hold that the issue fell within the ambit of Article 8, and therefore Article 14 was simply inapplicable. A small gesture in favour of such a duty can, however, be detected in Glor, where the applicant was deemed incapable of undertaking compulsory military service because of his diabetes, but was required to pay a substantial tax as a substitution. The Court held that a suitable alternative form of service compatible with his level of disability should have been offered to the applicant rather than imposing the substitution tax.

\section{Conclusion}

In recent years, the Strasbourg Court has been receptive to the importance of framing an equality guarantee that is responsive to the complex ways in which inequalities manifest. While not consciously formulating the conception as a multi-dimensional notion of substantive equality, its judgments have important resonances with this approach, particularly in relation to redressing disadvantage; addressing stigma, stereotyping and violence; and

\footnotetext{
${ }^{143}$ Kiss, supra n 31 at para 14.

${ }^{144}$ Botta v Italy, Application No. 21439/93, Merits, 24 February 1998 at para 35.
} 
enhancing participation. It remains cautious, however, in relation to transformation or structural change, with its one major contribution being in relation to parental leave for fathers. In relation to disability, it is still far behind other jurisdictions, which have made a significant commitment to reasonable accommodation; and it is still reluctant to take the step towards requiring recognition of same-sex marriage. More worrying is its tendency to revert unexpectedly to a formal understanding, as in the racial violence cases, which required intention, and the recent transgender case, which insisted on a like for like comparison. Although the Court's position as a supranational tribunal carries with it some inherent limitations, it is hoped that in this particularly precarious time for human rights, it continues to develop a robust understanding of the right to equality in its substantive sense. 